\title{
ANALIZA SYTUACJI MEODYCH LUDZI NA RYNKU PRACY - ROZWAŻANIA TEORETYCZNE I BADANIA EMPIRYCZNE
}

\begin{abstract}
Celem opracowania była analiza sytuacji ludzi młodych na polskim rynku pracy. Sytuacja ta jest bardzo niekorzystna. Młode osoby, mimo że są dobrze wykształcone, są dyskryminowane ze względu na wiek i brak doświadczeń zawodowych. Niechętnie są zatrudniane, a pracodawcy, którzy decydują się na ich zatrudnienie, wybierają najczęściej umowy czasowe, proponują bardzo niskie (minimalne) stawki płac. Wszystko to powoduje, że ta grupa zagrożona jest wysokim poziomem bezrobocia oraz związanym z tym wykluczeniem, ubóstwem. Niestety współcześnie nawet wyższe wykształcenie nie gwarantuje już pracy. Co więcej, zauważa się w tym względzie pewną negatywną prawidłowość - im młodsza i lepiej wykształcona grupa, tym gorsza jej sytuacja na rynku pracy. W związku z bardzo negatywną sytuacją ludzi młodych bardzo aktywnych, dobrze wykształconych osób (a jednocześnie niezadowolonych, sfrustrowanych) podejmuje trudną decyzję o wyjeździe za granicę w celu poszukiwania zatrudnienia. Skutki nadmiernej emigracji młodzieży są bardzo negatywne zarówno dla nich samych, jak i dla regionu, w którym mieszkaliby i pracowali, oraz dla gospodarki całego kraju, która traci w ten sposób tkwiący w nich ogromny potencjał. W kontekście bardzo trudnej sytuacji ludzi młodych na rynku pracy istotne wydaje się promowanie wśród nich kariery przedsiębiorcy. Złagodziłoby to napięcia na rynku pracy, poprawiło sytuację nie tylko tej grupy wiekowej, przyczyniłoby się do obniżenia poziomu bezrobocia. Rozważania teoretyczne na temat sytuacji ludzi młodych na rynku pracy zostały w opracowaniu poparte badaniami własnymi autorek przeprowadzonymi wśród 150 młodych osób z województwa podkarpackiego.

Słowa kluczowe: ludzie młodzi, rynek pracy, dyskryminacja, bezrobocie, emigracja.
\end{abstract}

\section{WSTĘP}

Wchodzenie na rynek, poszukiwanie pierwszej pracy nigdy i nigdzie nie są łatwe, a w okresach kryzysów sytuacja ludzi młodych rozpoczynających karierę zawodową, poszukujących pierwszej pracy dodatkowo się pogarsza ${ }^{3}$. Skutkiem tego jest rosnące bezrobocie w tej grupie wiekowej, a coraz więcej osób aktywnych, dobrze wykształconych w najlepszym okresie swego życia (prywatnego i zawodowego) decyduje się na migrację w poszukiwaniu pracy. $\mathrm{W}$ artykule omawiono przedstawione zagadnienia związane $\mathrm{z}$ sytuacja ludzi młodych na rynku pracy i w pracy zawodowej. Zawarte w nim rozważania oparto na dostępnej literaturze przedmiotu oraz na badaniach własnych przeprowadzonych przez

\footnotetext{
${ }^{1}$ Dr Teresa Piecuch, Katedra Przedsiębiorczości, Zarządzania i Ekoinnowacyjności, Wydział Zarządzania Politechnika Rzeszowska, Al. Powstańców Warszawy 8, 35-959 Rzeszów, e-mail: tpiecuch@prz.edu.pl (autor korespondencyjny)

${ }^{2}$ Mgr Małgorzata Piecuch.

${ }^{3}$ Zobacz szerzej T. Piecuch, Przedsiębiorczość. Podstawy teoretyczne, wyd. 2, C.H. Beck, Warszawa 2013, s. 214 n.
} 
autorki opracowania wśród 150 ludzi młodych województwa podkarpackiego, głównie studentów różnych wydziałów (różnych kierunków i typów studiów) Politechniki Rzeszowskiej. Zakres czasowy badań obejmuje okres od marca do maja 2013 r. Wykorzystaną metodą badawczą była ankieta (w przeważającej części z udziałem ankietera) oparta na standaryzowanym kwestionariuszu. Zastosowano celowy dobór próby badawczej - chodziło bowiem o uzyskanie opinii na analizowany temat od jak największej grupy młodych ludzi, wchodzących na rynek pracy. Badaniom poddano studentów Politechniki Rzeszowskiej ostatnich lat studiów licencjackich i magisterskich uzupełniających, stacjonarnych i niestacjonarnych. Rezultaty badań zaprezentowano w niniejszym opracowaniu.

\section{LUDZIE MŁODZI NA RYNKU PRACY}

Młodzi ludzie stanowią specyficzną grupę społeczno-zawodową - duża część ich aktywności przeznaczona jest na edukację oraz poszukiwanie (najczęściej pierwszej) pracy, którą dodatkowo często zmieniają w celu znalezienia najlepszego dla siebie miejsca. Szacuje się, że obecne pokolenie młodych osób wchodzących na rynek pracy jest czterokrotnie lepiej wykształcone niż pokolenie ich rodziców - ludzi obecnie pracujących. Mimo to bardzo trudno im znaleźć satysfakcjonującą lub jakąkolwiek pracę. Niechętnie są zatrudniani (nawet po studiach), dlatego że nie mają doświadczenia zawodowego. Wymagają ponadto dużych nakładów na dalsze kształcenie pod kątem wykonywania pracy na konkretnym stanowisku. Wśród pracodawców panuje także opinia o dużej rotacji wśród młodych pracowników, którzy chętnie zmieniają pracę, poszukują miejsca dla siebie, pragną zdobyć doświadczenie na wielu różnych stanowiskach.

Badane młode osoby zapytano między innymi o ocenę ich sytuacji na rynku pracy. Najwięcej z nich stwierdziło, że jest ona zdecydowanie zła - 62\% wskazań. Następna w kolejności wskazywana odpowiedź brzmiała: „bardzo zła” - 14\%. W sumie aż $76 \%$ respondentów oceniło sytuację młodych ludzi na rynku pracy zdecydowanie negatywnie. Jedynie $2 \%$ uznało, że jest ona bardzo dobra (rys. 1).

Młodzi ludzie często są dyskryminowani ze względu na wiek oraz brak doświadczenia zawodowego. Wszystko to powoduje, że pracodawcy preferują osoby doświadczone, z ustabilizowaną sytuacją rodzinną. Decydując się na zatrudnienie kogoś młodego, najczęściej wybierają umowy czasowe, krótkoterminowe, tłumacząc się chęcią sprawdzenia ich wiedzy, kwalifikacji i przydatności do realizacji określonych zadań. Niestety bardzo często umowy te nie są przedłużane, a na wolne miejsce pracy zatrudnia się kolejną młodą osobę. Aż 75\% badanych młodych osób województwa podkarpackiego przyznało, że czują się dyskryminowani na rynku pracy, że odczuwa negatywne nastawienie pracodawców na przykład w trakcie rozmów kwalifikacyjnych. W szczególnie trudnej sytuacji są młode kobiety.

$\mathrm{Na}$ problemy ludzi młodych na rynku pracy dodatkowo wpływają - wynikające z różnic pokoleniowych - problemy z komunikacją między nimi (przyszłymi pracownikami) a ich pracodawcami. Przedsiębiorcy często sygnalizują trudności w relacjach. Wymusza to na przykład zmianę sposobów podejścia do młodych pracowników, dlatego że „nie uznają oni autorytetów, mając niejako naturalną skłonność do kwestionowania poleceń przełożonych. Ponadto w przeciwieństwie do pokolenia ich rodziców, praca nie jest dla nich tak ważną wartością. Starają się łączyć ją z życiem osobistym i nie są zbyt lojalni 
wobec pracodawcy"4. To pokolenie Y, które stanowi ogromne wyzwanie dla kadr zarządzających współczesnych przedsiębiorstw. Trudno nimi kierować. Nie sprawdzą się wobec nich metody oparte na przymusie, rygorze, rozkazach. Lepiej dać im więcej swobody, umożliwić wykazanie się. Przedstawiciele pokolenia Y są aktywni, zaangażowani, pewni siebie, zmotywowani. Znają swoją wartość, oczekują relacji partnerskich, możliwości rozwoju. Jeżeli przedsiębiorstwo im tego nie zapewni, wolą odejść z pracy. Nie chcą tak ciężko pracować jak ich rodzice, chcą korzystać z życia, czerpać z pracy przyjemność. Niełatwo nimi kierować, ale warto wykorzystać ich potencjał i talenty.

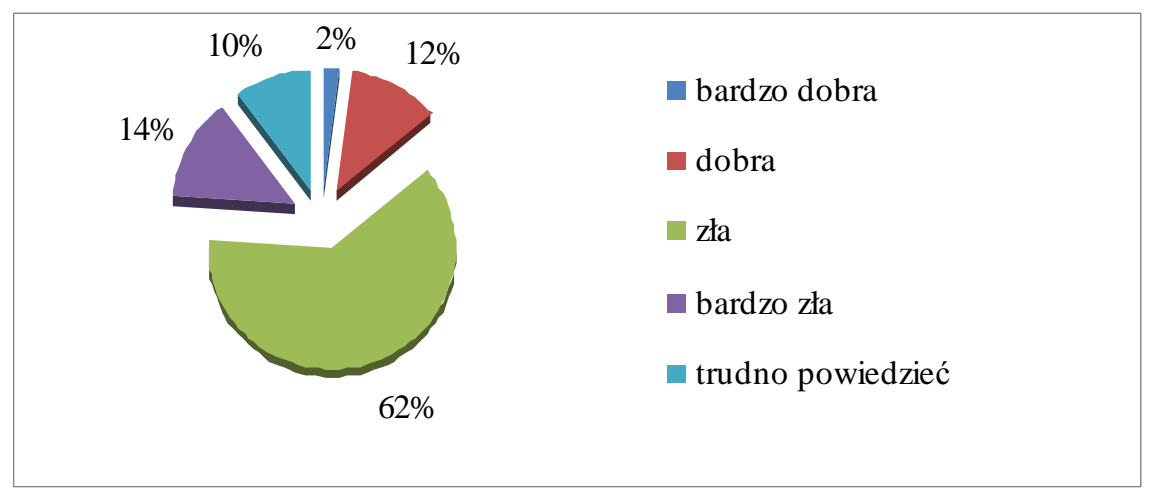

Rys. 1. Sytuacja ludzi młodych na rynku pracy

Źródło: Opracowanie własne na podstawie przeprowadzonych badań empirycznych.

Badanych przez autorki opracowania respondentów zapytano także o to, jak - ich zdaniem - można zwiększyć szanse młodych ludzi na rynku pracy (rys. 2). Najczęściej wskazywano na:

- naukę języków - 20\%;

- $\quad$ praktyki krajowe i zagraniczne - $18 \%$;

- podnoszenie kwalifikacji - $18 \%$.

Najmniej badanych opowiedziało się za wolontariatem - był on ważny dla zaledwie $2 \%$ respondentów. W polskich warunkach gospodarowania nie jest on zbyt popularny wśród młodych ludzi. Nie postrzegają go jako szansy na zdobycie doświadczenia, na poznawanie nowych, wartościowych ludzi, na rozwijanie - bardzo pożądanych przez pracodawców - kompetencji społecznych. Młodym ludziom wydaje się, że potencjalni pracodawcy nie zwracają uwagi na znaczenie tego typu aktywności. W dziedzinie wolontariatu polska młodzież zajmuje bardzo odległe pozycje w badaniach europejskich. Według Eurobarometru ${ }^{5}$ jedynie $16 \%$ młodych Polaków angażuje się w tego typu działania (średnia europejska to 24\%). W Europie najbardziej aktywni pod tym względem są Holendrzy - około $40 \%$ młodych obywateli tego państwa było wolontariuszami w ostatnim roku. Okazuje się, że pracodawcy bardzo pozytywnie postrzegają aktywność w wolontariacie - ich zdaniem świadczy to o aktywności, potrzebie rozwoju, zaradności, dojrzałości życiowej, zaangażowaniu, przedsiębiorczości przyszłych pracowników, która może być przez nich spożytkowana w przyszłej pracy.

\footnotetext{
${ }^{4}$ Zarzadzanie. Tradycja i nowoczesność, red. J. Bogdaniecki, W. Piotrowski, PWE, Warszawa 2013, s. 347. ${ }^{5}$ http://polska.newsweek.pl/eurobarometr--mlodzi-polacy-nie-angazuja-sie-w-wolontariat,76828,1,1.html (do-
} stęp: 10.11.2013). 


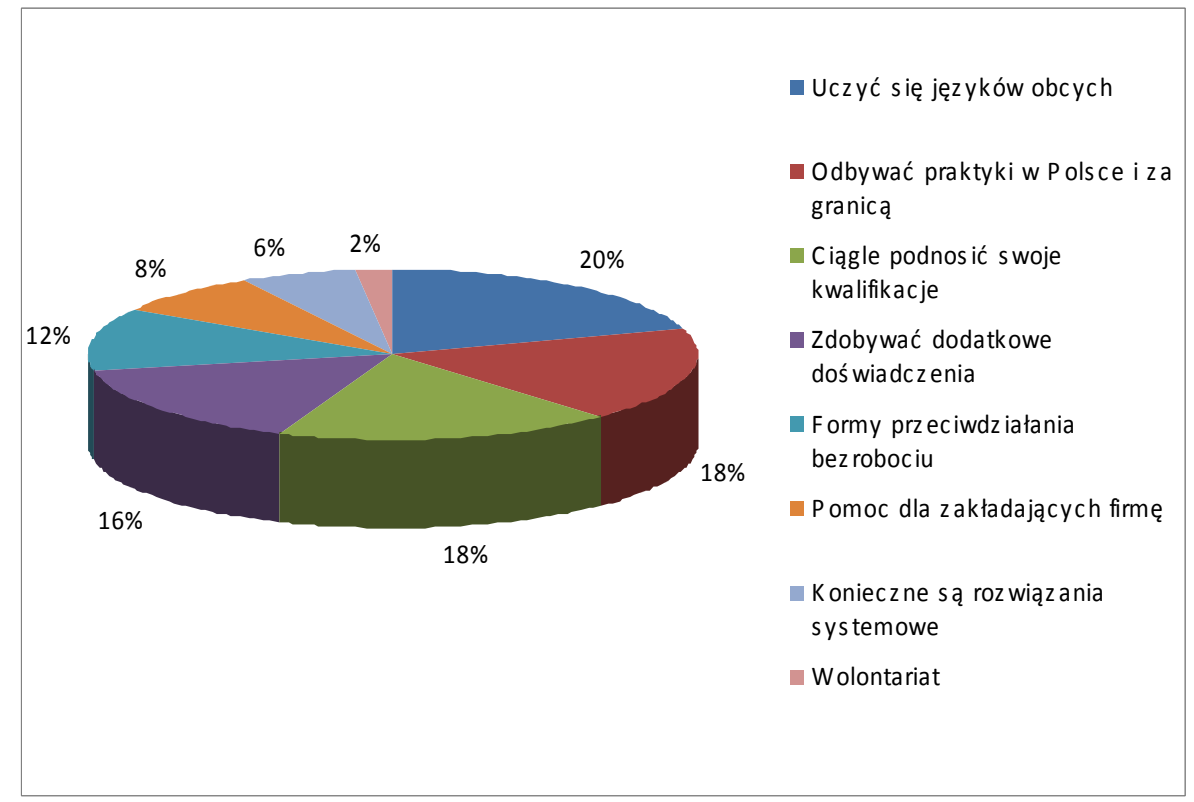

Rys. 2. Jak można zwiększyć szanse młodych ludzi na rynku pracy?

Źródło: Opracowanie własne na podstawie przeprowadzonych badań empirycznych.

Często do opisu sytuacji ludzi młodych na rynku pracy wykorzystuje się kategorię $\mathrm{NEET}^{6}$. Jest ona bardzo różnorodna $\mathrm{i}$ - generalnie - mieści w sobie bezrobotnych poszukujących pracy oraz osoby z różnych powodów wykluczone z rynku, na przykład długotrwale chore, niepełnosprawne, opiekujące się dziećmi lub krewnymi. Są to zatem osoby szczególne, generujące największze koszty społeczne ${ }^{7}$, obarczone „wysokim ryzykiem społecznej ekskluzji, pozostające poza układem instytucji pozwalających na nabywanie bądź aktualizację niezbędnych na rynku pracy kwalifikacji i umiejętności, a także innych kompetencji społecznych i obywatelskich", . W literaturze do czynników zwiększających prawdopodobieństwo przynależności do grupy NEET zalicza się ${ }^{9}$ :

\footnotetext{
${ }^{6}$ Termin ten pochodzi z języka angielskiego i oznacza not in employment, and education and training, a zatem osoby: niezatrudnione, nieuczace się ani nieszkolone. Skrót ten po raz pierwszy pojawił się w Stanach Zjednoczonych pod koniec lat osiemdziesiątych XX w. i odzwierciedlał alternatywny sposób klasyfikowania młodzieży po wprowadzeniu zmian w polityce w obszarze zasiłków dla bezrobotnych. Młodzi ludzie i młodzież bierna spotecznie (tzw. Grupa NEET) w Europie: podstawowe ustalenia, s. 2, http://eurofund.europa.eu (dostęp: 12.01.2015).

${ }^{7}$ Konsekwencje przynależności do grupy NEET odczuwa nie tylko jednostka, ale i społeczeństwo, gospodarka. Generuje to nie tylko koszty społeczne, ale i ekonomiczne. Przykładem mogą być: (1) koszty zasiłków, opieki społecznej; (2) wyższe wydatki na opiekę zdrowotną; (3) wyższe koszty funkcjonowania wymiaru sprawiedliwości w sprawach karnych. Warto także zwrócić uwagę na tzw. koszty utraconych możliwości - szacowane straty dla gospodarki wynikajace z niezatrudniania ludzi wartościowych, z potencjałem, mających doświadczenie, ale niemających możliwości, by urzeczywistnić je w praktycznym działaniu Młodzi ludzie i młodzież bierna spotecznie..., s. 4.

${ }^{8}$ M. Pańków, Młodzi na rynku pracy. Raport z badania, Wydawnictwo Instytutu Spraw Publicznych, Warszawa 2012, s. 14.

${ }^{9}$ Mtodzi ludzie i młodzież bierna społecznie..., s. 3.
} 
- $\quad$ pewien sposób (rodzaj) niepełnosprawności;

- $\quad$ pochodzenie ze środowisk imigracyjnych;

- niskie wykształcenie;

- $\quad$ życie na obszarach peryferyjnych;

- $\quad$ przynależność do gospodarstw domowych o niskich dochodach;

- posiadanie rodziców, którzy doświadczyli bezrobocia, mają niskie wykształcenie lub są rozwiedzeni.

Udział kategorii NEET w wybranych krajach Unii Europejskiej zawarto w tabeli 1.

Tabela 1. Kategoria NEET w wybranych krajach Unii Europejskiej (UE) w roku 2011

\begin{tabular}{|l|c|c|c|}
\hline \multicolumn{1}{|c|}{ Wyszczególnienie } & $\mathbf{1 8 - 2 4}$ lat & $\mathbf{2 5 - 2 9}$ lat & Razem \\
\hline UE & $\mathbf{1 6 , 5 \%}$ & $\mathbf{1 9 , 7 \%}$ & $\mathbf{3 6 , 2 \%}$ \\
\hline Bułgaria & $27,0 \%$ & $27,0 \%$ & $54,0 \%$ \\
\hline Włochy & $26,5 \%$ & $24,5 \%$ & $51,0 \%$ \\
\hline Węgry & $16,5 \%$ & $24,0 \%$ & $40,5 \%$ \\
\hline Słowacja & $27,0 \%$ & $18,0 \%$ & $45,0 \%$ \\
\hline Dania & $8,0 \%$ & $9,0 \%$ & $17,0 \%$ \\
\hline Holandia & $6,0 \%$ & $8,5 \%$ & $14,5 \%$ \\
\hline Polska & $\mathbf{1 4 , 0 \%}$ & $\mathbf{2 2 , 0 \%}$ & $\mathbf{3 6 , 0 \%}$ \\
\hline
\end{tabular}

Źródło: M. Pańków, Młodzi na rynku pracy. Raport z badania, Wydawnictwo Instytutu Spraw Publicznych, Warszawa 2012, s. 12 n., forsal.pl (dostęp: 12.01.2015).

$\mathrm{Z}$ informacji zawartych $\mathrm{w}$ tabeli 1 wynika, że najtrudniejsza sytuacja pod względem kryterium NEET w 2011 r. była w Bułgarii. W Polsce była ona dość korzystna. W kategorii wiekowej 18-24 lat udział osób niezatrudnionych, nieuczących się i nieszkolących się kształtował się bowiem nieco poniżej średniej unijnej - mniej o 2,5\%, a w grupie wiekowej 25-29 lat był wyższy od średniej unijnej o 2,3\%. Dobry wynik Polski w tej kategorii wynika z wysokiego odsetka ludzi młodych studiujących (często na wielu kierunkach studiów) i uczących się, co w mniemaniu młodych osób zwiększa szanse na znalezienie dobrej pracy (nie sprawdza się to jednak w praktyce). Kraje o najniższym wskaźniku NEET w 2011 r. to: Dania, Holandia i Luksemburg ${ }^{10}$.

Osoby zaliczane do kategorii NEET powinny być objęte programami szkoleń, praktyk umożliwiających im ponowne zaistnienie na rynku pracy, prowadzących docelowo do zatrudniania ich na różnorodnych stanowiskach.

\section{POZIOM BEZROBOCIA WŚRÓD LUDZI MŁODYCH}

Sytuacja młodych ludzi na rynku pracy jest bardzo trudna. Wynika to między innymi z bardzo wysokiego poziomu bezrobocia w tej grupie wiekowej. W niektórych krajach Unii Europejskiej przekracza on nawet 50\%. Coraz częściej młodzi ludzie mają ogromne problemy ze znalezieniem zatrudnienia i to niezależnie od tego, jaką szkołę ukończyli (ile kierunków studiów), jaki zdobyli zawód. Problemem jest również to, że także wyższe wykształcenie nie gwarantuje już obecnie zatrudnienia, co więcej - nie zwiększa nawet szans na znalezienie satysfakcjonującej pracy. Analizując sytuację ludzi młodych na ryn-

\footnotetext{
${ }^{10}$ Brak informacji na temat kształtowania się NEET w województwie podkarpackim. W opracowaniu traktuje się jednak omawianą kategorię jako dodatkową, uzupełniającą prowadzoną analizę dotyczącą sytuacji ludzi młodych na rynku pracy.
} 
ku pracy, można zauważyć następującą prawidłowość - im młodsza i lepiej wykształcona grupa, tym jej sytuacja jest gorsza. Powodów takiego stanu rzeczy jest wiele. Komisja Europejska wskazała na następujące przyczyny bezrobocia wśród młodzieży ${ }^{11}$ :

- $\quad$ przedwczesne kończenie nauki bez kwalifikacji;

- brak odpowiednich umiejętności i doświadczenia zawodowego;

- $\quad$ niepewne formy zatrudnienia, a następnie okresy bezrobocia;

- $\quad$ ograniczone możliwości szkoleń;

- $\quad$ niewystarczające/niewłaściwe programy rynku pracy sprzyjające aktywności.

Autorki opracowania zapytały badaną grupe jakie są - w odczuciu młodych ludzi przyczyny bezrobocia $w$ ich grupie wiekowej. Najczęściej wskazywano na zbyt duże wymagania pracodawców - 55\% oraz nieodpowiednią politykę rządu w stosunku do tej grupy wiekowej - 52\%. Najrzadziej respondenci wskazywali na brak chęci ludzi młodych do pracy $-9 \%$. Informacje na ten temat zawarto na rysunku 3.

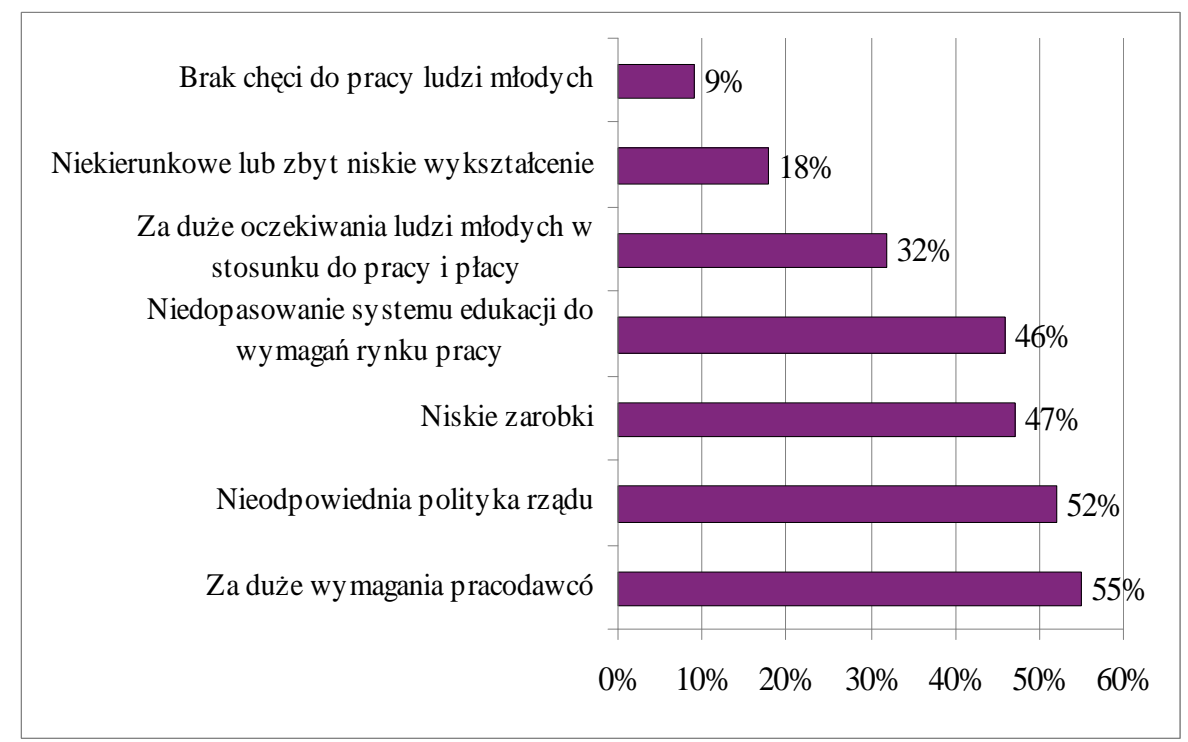

Rys. 3. Jakie są przyczyny bezrobocia ludzi młodych?

Źródło: Opracowanie własne na podstawie przeprowadzonych badań empirycznych.

Bardzo istotnym powodem wysokiego poziomu bezrobocia w grupie ludzi młodych jest to, że ich wykształcenie nie idzie w parze z potrzebami rynku pracy. Jak podkreślają specjaliści: ,„pracodawcy, szkoły i młodzi ludzie żyją w równoległych światach i jeżeli nie zaczną współpracować, nic się nie zmieni”" ${ }^{2}$. Umiejętności młodych ludzi nie są dostosowane do tego, czego żąda od nich rynek pracy. „Efektem tego jest to, że z jednej strony osobom z najniższym wykształceniem bardzo trudno znaleźć pracę, a z drugiej - rośnie

\footnotetext{
${ }^{11}$ Zatrudnienie młodzieży: perspektywy, http://europa.eu/legislation_summaries/employment_and_social_policy/ community_employment_policies/em0054_pl.htm (dostep: 11.05.2013).

${ }^{12}$ http://wyborcza/biz/biznes/1,100896,13874661,To_nie_jest_swiat_dla_mlodych_ludzi_html (dostęp: 2.08.2013).
} 
armia absolwentów wyższych uczelni, którzy pracują na nisko płatnych stanowiskach poniżej ich wykształcenia i aspiracji”, ${ }^{\prime \prime}$.

W tabeli 2 zawarto informacje na temat poziomu bezrobocia wśród ludzi młodych w Polsce i Unii Europejskiej w latach 2002-2011.

Tabela 2. Poziom bezrobocia w grupie wiekowej 15-24 lat w Polsce i Unii Europejskiej w latach 2002-2014

\begin{tabular}{|c|c|c|}
\hline Lata & Polska & Unia Europejska \\
\hline $\mathbf{2 0 0 2}$ & $42,5 \%$ & $17,8 \%$ \\
\hline $\mathbf{2 0 0 3}$ & $41,9 \%$ & $18,6 \%$ \\
\hline $\mathbf{2 0 0 4}$ & $39,6 \%$ & $19,0 \%$ \\
\hline $\mathbf{2 0 0 5}$ & $36,9 \%$ & $18,8 \%$ \\
\hline $\mathbf{2 0 0 6}$ & $29,8 \%$ & $17,5 \%$ \\
\hline $\mathbf{2 0 0 7}$ & $21,7 \%$ & $15,7 \%$ \\
\hline $\mathbf{2 0 0 8}$ & $17,3 \%$ & $15,8 \%$ \\
\hline $\mathbf{2 0 0 9}$ & $20,6 \%$ & $20,1 \%$ \\
\hline $\mathbf{2 0 1 0}$ & $23,7 \%$ & $21,1 \%$ \\
\hline $\mathbf{2 0 1 1}$ & $25,8 \%$ & $21,4 \%$ \\
\hline $\mathbf{2 0 1 2}$ & $26,5 \%$ & $23,5 \%$ \\
\hline $\mathbf{2 0 1 3}$ & $27,3 \%$ & $23,3 \%$ \\
\hline Listopad 2014 & $23,2 \%$ & $21,9 \%$ \\
\hline
\end{tabular}

Źródło: Opracowanie własne na podstawie: M. Pańków, op. cit., s. 11; forsal.pl (dostęp: 12.01.2015).

Jak wynika z tabeli 2 - sytuacja w zakresie poziomu bezrobocia ludzi młodych w Polsce w porównaniu do UE nie jest tak bardzo niekorzystna. Od 2002 r. można zauważyć systematyczny spadek jego poziomu w Polsce z jednoczesnym wzrostem w UE. Ponadto widoczne jest wyraźne pogorszenie sytuacji w tym względzie (zarówno w Polsce, jak i w UE) w 2008 r. wskutek światowego kryzysu gospodarczego i w kolejnych latach aż do $2013 \mathrm{r}$.

\section{PROBLEM MIGRACJI LUDZI MLODYCH}

Wysokie bezrobocie w grupie ludzi młodych wywołuje niezadowolenie, frustracje. Trudno bowiem planować karierę zawodową i życie prywatne bez poczucia bezpieczeństwa materialnego, pewności zatrudnienia, które daje stała praca, a nie terminowe kontrakty, umowy śmieciowe. Często bywa to także przyczyną decyzji o wyjeździe za granicę w poszukiwaniu zatrudnienia.

Problem migracji wśród młodych ludzi w Polsce (także w województwie podkarpackim) jest bardzo istotny. Młodzież często nazywana jest „straconym pokoleniem”, które jedyną dla siebie szansę upatruje w emigracji zarobkowej. Zjawisko to występowało zawsze. Od wieków ludzie przemieszczali się, poszukując dla siebie jak najatrakcyjniejszego miejsca do życia i pracy. Charakterystyczną cechą obecnej polskiej emigracji (bardzo niekorzystna) jest jednak to, że najczęściej wyjeżdżają dobrze wykształceni młodzi ludzie, którzy mimo chęci nie są w stanie znaleźć pracy w kraju, zacząć dorosłego życia w panu-

\footnotetext{
${ }^{13}$ Ibidem.
} 
jących warunkach. Najczęściej ich wyjazdy powodują, że gospodarka traci ogromny, tkwiący w nich potencjał.

Za granicę wyjeżdżają ludzie bardzo dobrze wykształceni. Spowodowany tym ubytek bardzo trudno uzupełnić. Wysoki odsetek emigracji młodych ludzi z Polski to także ogromny problem demograficzny. Pod koniec sierpnia 2012 r. Brytyjski Urząd Statystyczny podał, że co czwarte z około 720 tys. urodzonych tam dzieci w 2011 r. miało matkę pochodzenia innego niż brytyjskie. Liczba urodzonych dzieci w Wielkiej Brytanii przez imigrantki wciąż rośnie, a aż około 20 tys. matek cudzoziemek stanowią Polki. Około 15 tys. ojców dzieci, które urodzone zostały przez Polki to również Polacy, a pozostali to cudzoziemcy. Wynika z tego, że co czwarta kobieta pochodzenia polskiego ma dziecko nie z Polakiem. Natomiast w odróżnieniu od kobiet, większość polskich ojców ma potomstwo z rodaczkami, co wskazuje na to, że kobiety łatwiej i szybciej się integruja w obcym kraju niż mężczyźni ${ }^{14}$.

Młody człowiek, który decyduje o wyjeździe za granicę, często jest zmuszony opuścić kraj, mimo że tego nie chce. Powodem jest międzynarodowe zróżnicowanie stawek płac, które odzwierciedlają poziom rozwoju gospodarczego danego kraju. Ludzie chcący poprawić swoją sytuację ekonomiczną zazwyczaj wybierają migrację jako środek realizacji tego celu. Jeżeli znajdują pracę w Polsce, często jest ona poniżej ich kwalifikacji, co też ma znaczny wpływ na decyzję o emigracji. Oczekują lepszych warunków pracy, która jest zgodna z ich wykształceniem, a mogą to szybciej osiągnąć właśnie za granicami kraju. Również oczekiwana przez nich wielkość wynagrodzenia (nawet jeśli emigranci zaliczają się do grupy najmniej zarabiającej w danym kraju) jest satysfakcjonująca. To powoduje, że kraj imigracji bogaci się dzięki taniej sile roboczej, która nie jest konkurencją dla miejscowych pracowników ${ }^{15}$.

Badane młode osoby z województwa podkarpackiego także zapytano o kwestię emigracji. Aż $76 \%$ z nich przyznało, że bierze pod uwagę wyjazd za granicę, by znaleźć pracę, zapewnić sobie źródło utrzymania, uniezależnić się od rodziców, móc założyć rodzinę. Bardzo wielu ich znajomych (55\%) również przebywa za granicą. Zaledwie $3 \%$ respondentów stwierdziło, że nie ma znajomych na emigracji (rys. 4). Z opublikowanego przez Komisję Europejską w listopadzie 2008 r. raportu wynika, że obywatele Polski stanowią największą grupę migrantów w krajach UE. Według Głównego Urzędu Statystycznego najwięcej młodych ludzi emigruje do Wielkiej Brytanii - 30\%, Niemiec - 22\%, Stanów Zjednoczonych $-12 \%$, Irlandii - 7\%, Włoch - 3\%.

Emigracja młodych ludzi jest poważnym negatywnym skutkiem wysokiego bezrobocia w tej grupie wiekowej, które uniemożliwia normalne życie. Powoduje frustracje, poczucie bezsensu życia i studiowania (często wielu kierunków), konieczność bycia zależnym rodziców. Odsuwa ponadto w czasie moment założenia rodziny i posiadania dzieci. Młodzi ludzie zmuszeni są poszukiwać innych rynków pracy, aby móc zaspokoić swoje podstawowe potrzeby. Jeżeli wyjeżdżają, to przede wszystkim z powodów ekonomicznych. Są bardziej mobilni, co pomaga im w zaaklimatyzowaniu się w nowym kraju (choć dla bardzo wielu $\mathrm{z}$ nich zderzenie $\mathrm{z}$ inną kulturą powoduje wiele problemów). W większości są jednak zadowoleni z wyboru, jakiego dokonali, wyjeżdżając. Niepokojące jest to, że zdecydowana większość $\mathrm{z}$ nich nie deklaruje chęci powrotu w najbliższej przyszłości

\footnotetext{
${ }^{14}$ http://www.biuletynmigracyjny.uw.edu.pl/38-pazdziernik-listopad-2012/na-wyspach-wciaz-kroluja-matkipolki (dostęp: 13.01.2013).

${ }^{15}$ E. Śpiewak, op. cit., s. 299-301.
} 
z powodu braku perspektyw w kraju. Polska zatem musi podjąć działania, mające na celu usprawnienie rynku pracy, by emigranci mieli silną motywację do powrotu do ojczyzny, by mogli w kraju ojczystym wykorzystać zaangażowanie, energię i potencjał.

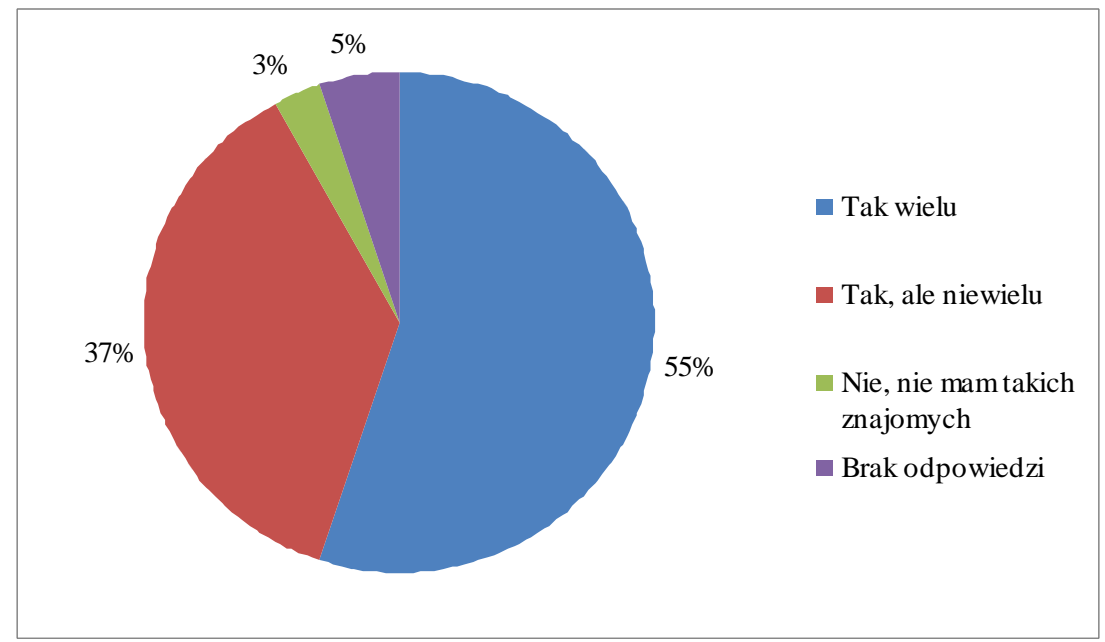

Rys. 4. Czy wielu Twoich znajomych przebywa za granicą?

Źródło: Opracowanie własne na podstawie przeprowadzonych badań empirycznych.

Badane młode osoby zamieszkałe na obszarze województwa podkarpackiego również zapytano o to, do jakiego kraju planują wyjechać za granicę w celu znalezienia pracy (rys. 5). Najczęściej wskazywali oni na: Anglię - 42\%, Niemcy - 21\%, Norwegię - 12\%, Holandię $-11 \%$.

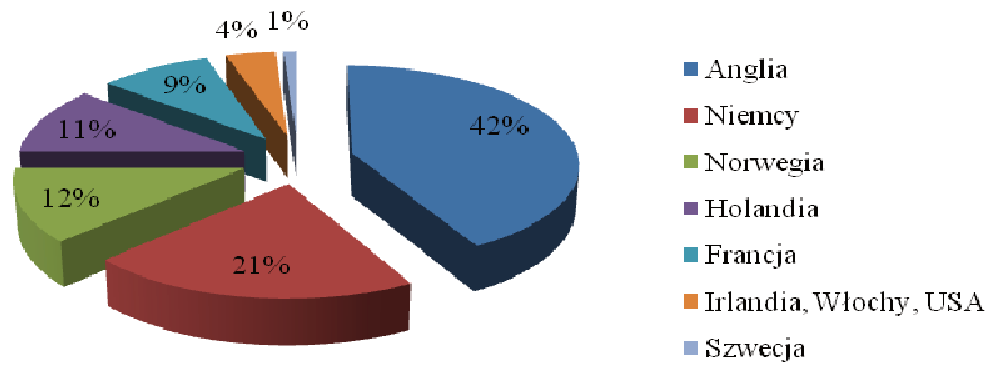

Rys. 5. Migracja - kraj docelowy

Źródło: Opracowanie własne na podstawie wyników badań empirycznych. 


\section{PROMOWANIE PRZEDSIĘBIORCZOŚCI WŚRÓD LUDZI MLODYCH SZANSĄ NA POPRAWE ICH SYTUACJI NA RYNKU PRACY}

W kontekście bardzo trudnej sytuacji ludzi młodych na rynku pracy bardzo istotne jest popieranie przedsiębiorczości w tej grupie wiekowej. Dzięki ich aktywnym postawom i zachowaniom mogą oni stworzyć dla siebie warunki, w których będą mogli godnie żyć i pracować, a nie tylko biernie przystosowywać się do bardzo trudnej dla nich sytuacji. Dzięki takim postawom młodzi ludzie przyczyniają się do łagodzenia napięć na rynku pracy, zapewniają atrakcyjne miejsce pracy sobie i wielu innym młodym ludziom.

Badania wykazują, że młodzi ludzie są pozytywnie nastawieni do kariery przedsiębiorcy. Wielu z nich deklaruje chęć posiadania własnej firmy, jednak bardzo często rzeczywistość okazuje się dużo bardziej złożona, co weryfikuje ich deklaracje. W konsekwencji niewiele młodych ludzi zakłada firmy.

W prowadzonych przez autorki opracowania badaniach także znalazły się pytania odnoszące się do nastawienia respondentów wobec założenia własnej firmy w przyszłości. W jednym z nich zapytano o to, co badany byłby gotów zrobić, by znaleźć pracę. Najczęściej wskazywano na:

- $\quad$ wyjazd za granicę - 66\% wskazań;

- $\quad$ zmianę miejsca zamieszkania (w kraju) - 53\%;

- $\quad$ podjęcie każdej pracy - $48 \%$;

- $\quad$ przekwalifikowanie się-44\%;

- $\quad$ założenie własnej firmy - 43\%;

- pracę na czarno - 37\%.

W kolejnym pytaniu respondenci zostali poproszeni o wskazanie, co będą robić po zakończeniu studiów. Najwięcej z nich odpowiedziało, że chcą pracować w małej prywatnej firmie - 31\% wskazań. W korporacji chciałoby pracować $23 \%$ badanych, a za własną firmą opowiedziało się $21 \% \mathrm{z}$ nich (rys. 6).

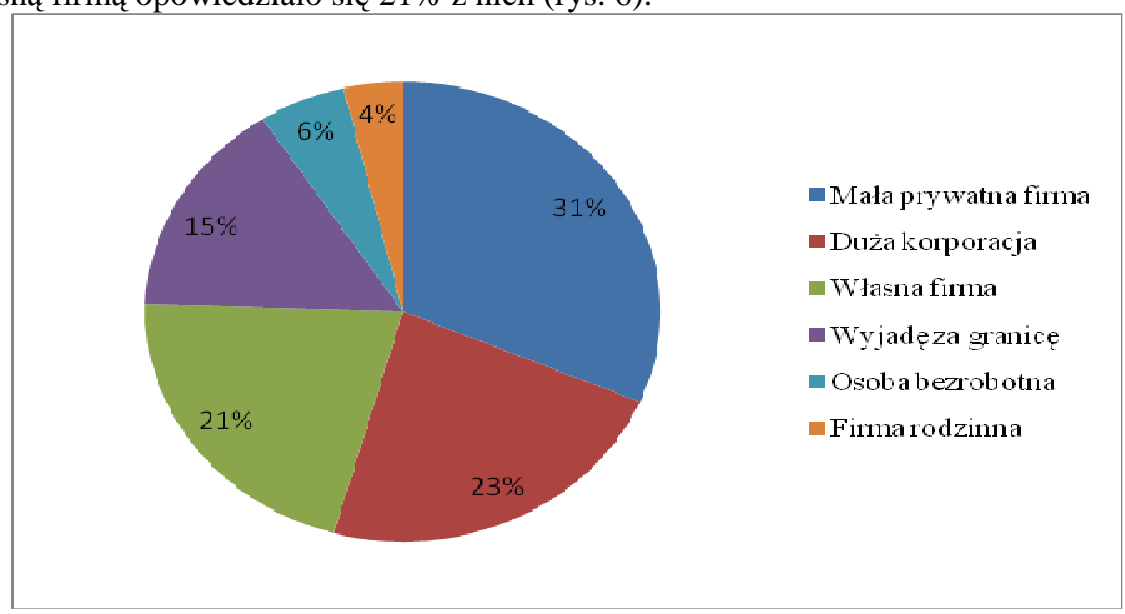

Rys. 6. Co zamierzasz robić po studiach?

Źródło: Opracowanie własne na podstawie przeprowadzonych badań empirycznych.

Specjaliści oceniają, że pokolenie ludzi młodych, które aktualnie podejmuje decyzje na rynku pracy, nawet jeżeli uwzględnia w swojej przyszłej karierze bycie przedsiębiorcą - nie jest (paradoksalnie) przedsiębiorcze. Przedsiębiorca powinien być pracowity, zaan- 
gażowany, skłonny do poświęceń. Młode pokolenie jest natomiast „zapatrzone w siebie, narcystyczne i uwiedzione przez konsumpcjonizm - główną siłę napędową współczesnego kapitalizmu. Oczekują szybkich efektów - chcą mieć wszystko i szybko. Tymczasem przedsiębiorcy potrzebna jest dyscyplina [...], kreatywność, pracowitość. Na sukces musi często cierpliwie czekać nawet kilka lat. Natomiast wyobrażenie dzisiejszej młodzieży o pracowitości i wyrzeczeniach wyczerpuje się na trudach związanych ze zdobywaniem wykształcenia"16. Na korzyść ludzi młodych przemawia fakt, że znają swoją wartość, są pewni siebie i są skłonni do podejmowania ryzyka.

Aby młodzi ludzie chcieli angażować się w podejmowanie i prowadzenie działalności gospodarczej, należy ich do tego przygotować. Bardzo ważną rolę odgrywa w tym środowisko rodzinne. Rodzice od najmłodszych lat powinni ,wychowywać dzieci w duchu przedsiębiorczości”, powinni uczyć je trudnej sztuki wydawania, gospodarowania pieniędzmi, a także zarabiania, oszczędzania, samodzielności w podejmowaniu decyzji, ducha zapobiegliwości i gospodarności ${ }^{17}$. Niezbędne są także rozwiązania systemowe, które będą wspierać wszystkich tych, którzy zdecydują się na trud bycia przedsiębiorcą.

\section{ZAKOŃCZENIE}

W opracowaniu starano się zaprezentować trudną sytuację ludzi młodych na rynku pracy. Wykorzystano w tym celu informacje dotyczące tego zagadnienia, a odnoszące się do UE, Polski, województwa podkarpackiego. Przeprowadzone na potrzeby opracowania badania własne potwierdzają, że sytuacja ludzi młodych jest bardzo zła, czują się oni dyskryminowani, a wymagania pracodawców często są niemożliwe do spełnienia przez nich. Brak pracy dla młodych ludzi planujących swoją zawodową i prywatną przyszłość jest ogromnie frustrujący $-\mathrm{z}$ tego powodu bardzo wielu $\mathrm{z}$ nich $\mathrm{w}$ poszukiwaniu zatrudnienia decyduje się na emigrację (potwierdza to aż $78 \%$ badanych). Gospodarka kraju traci $\mathrm{w}$ ten sposób ogromny potencjał aktywnych, pełnych zapału osób, które pracują w obcym kraju.

Bardzo niekorzystne jest także to, że trudna sytuacja młodych ludzi na rynku pracy powoduje, że coraz częściej podchodzą oni bardzo pragmatycznie do życia i własnej kariery - nie wybierają zawodu, który zapewni im samorealizację, spełnienie, umożliwi realizację pasji, zainteresowań, ale taki, który zagwarantuje środki utrzymania dla siebie i rodziny. Nie jest to pozytywne zjawisko - dobry, zaangażowany w pracę pracownik musi kochać to, co robi, praca powinna być zgodna z jego zainteresowaniami i aspiracjami.

\footnotetext{
${ }^{16}$ S. Wendziuk, Trzeba pobudzać przedsiębiorczość młodzieży, www.kariera.pb.pl (dostęp: 16.09.2013).

${ }^{17}$ Psychologowie podkreślają, że wychowując dzieci w duchu przedsiębiorczości, nie należy: (1) dawać pieniędzy za wykonywanie przez dziecko ich obowiązków (np. wyrzucanie śmieci, sprzątanie pokoju); (2) płacić za dobre stopnie w szkole; (3) dawać, zwłaszcza małym dzieciom, zbyt dużych kwot; (4) dawać dodatkowych kwot tylko dlatego, że dziecko wydało już posiadane oszczędności (nie uczy to gospodarności); (5) zabraniać samodzielnego finansowania drobnych zachcianek, takich jak lody, lizaki; (6) narzucać w każdym przypadku własnego zdania w kwestii wydawania pieniędzy; (7) wypłacać kieszonkowego w razie, gdy dziecko dopuszcza się poważnych wykroczeń, na przykład wagarowania; (8) wstrzymywać kieszonkowego za słabe stopnie, gdyż może to pogłębić problemy dziecka; (9) zabraniać dziecku zarabiania pieniędzy przez podejmowanie różnych drobnych prac, dostosowanych jednak do jego możliwości (np. roznoszenie ulotek, podlewanie u kogoś kwiatków itp.). H. Bieniok, Kształtowanie postaw przedsiębiorczych młodzieży w rodzinie, szkole, uczelni, fundacja.edu.pl/przedsiębiorczość/_referaty/sesja_IIIa/23.pdf (dostęp: 16.09.2013).
} 


\section{LITERATURA}

[1] forsal.pl

[2] fundacja.edu.pl/przedsiębiorczośćl_referaty/sesja_IIIa/23.pdf.

[3] http://eurofund.europa.eu.

[4] http://polska.newsweek.pl/eurobarometr--mlodzi-polacy-nie-angazuja-sie-wwolontariat, $76828,1,1 . h t m l$.

[5] http://wyborcza/biz/biznes/1,100896,13874661,To_nie_jest_swiat_dla_mlodych_ludzi_html.

[6] http://www.biuletynmigracyjny.uw.edu.pl/38-pazdziernik-listopad-2012/na-wyspach-wciazkroluja-matki-polki.

[7] http://europa.eu/legislation_summaries/employment_and_social_policy/community_employm ent_policies/em0054_pl.htm.

[8] Pańków M., Młodzi na rynku pracy. Raport z badania, Wydawnictwo Instytutu Spraw Publicznych, Warszawa 2012.

[9] Piecuch T., Przedsiębiorczość. Podstawy teoretyczne, wyd. 2, C.H. Beck, Warszawa 2013.

[10] Regionalne aspekty rynku pracy, red. A. Organiściak-Krzykowska, Wydawnictwo Uniwersytetu Warmińsko-Mazurskiego w Olsztynie, Instytut Pracy i Spraw Socjalnych w Warszawie, Warszawa-Olsztyn 2011.

[11] www.kariera.pb.pl.

[12] Zarzqdzanie. Tradycja i nowoczesność, red. J. Bogdaniecki, W. Piotrowski, PWE, Warszawa 2013.

\section{ANALYSIS OF THE SITUATION OF YOUNG PEOPLE IN THE LABOUR MARKET - THEORETICAL CONSIDERATIONS AND EMPIRICAL RESEARCH}

The main reason of the study was to present the situation of young people in the Polish labor market. This situation is very unfavorable. Young people, even though they are well educated, they are discriminated against because of their age and lack of professional experience. They are employed reluctantly and employers who choose them to employ, they usually choose temporary contracts which offer very low (minimum) wages. All of that means that this group is threatened by high level of unemployment, associated with this exclusion and poverty. Unfortunately, nowadays even higher education does not guarantee a good job. Moreover, in this case it a negative regularity can be noted - the younger and better educated group, the worse labor market situation they have. Well-educated and active young people very often make decision to go abroad in searching of employment. The effects of excessive emigration of young people are very negative, for them and for the region where they live and work as well, and for the economy of the whole country, which loses a great potential. In the context of a very difficult situation of young people in the labor market, it seems to be very important to promote entrepreneurial career. It could calm down the tensions inn the labor market and improved the situation in this age group, and also can help to reduce the level of unemployment. Theoretical considerations about the situation of young people in the labor market has been supported by studies of the authors, conducted among 150 young people from the Podkarpacie province.

Keywords: young people, discrimination, unemployment, emigration

\section{DOI: 10.7862/rz.2014.mmr.54}

Tekst złożono w redakcji: październik 2014

Przyjęto do druku: styczeń 2015 